\title{
Biometric Analysis of Some Internal Organs of Hybrids between the European Bison and Domestic Cattle
}

\author{
Małgorzata KRASIŃSKA \& Waldemar PILARSKI
}

\begin{abstract}
Krasińska M. \& Pilarski W., 1977: Biometric analysis of some internal organs of hybrids between the European bison and domestic cattle. Acta theriol., 22, 6: 121-138 [With 8 Tables \& 3 Figs.].

The liver, heart and kidneys of 32 hybrids of different generations between the European bison and domestic cattle were subjected to a biometric analysis and the results obtained were compared with data for the initial forms. Despite a great difference in body weight $(80 \%)$ $F_{1}$ males have a relatively lighter liver, heart and kidneys than females. In $B_{1}$ males the weight of the heart in relation to that of body is larger and the weights of the liver and kidneys smaller than in females. The liver and heart of both sexes of $F_{1}$ hybrids and the kidneys of males are heavier in relation to body weight than they are in the two initial forms. In the $\mathrm{B}_{1}$ generation the liver and heart also have a higher relative weight than they have in the European bison and cattle, but the differences are smaller than in the case of $F_{1}$ hybrids except the relative weight of the liver in $B_{1}$ females. As regards the build of these internal organs, the European bison characters are dominant in the liver (thickness, backwardness of the left lobe as compared with the size of the right and quadrate lobes) and in the number of the renal lobes. The dominance of the cattle characters was found in the size of the caudate process of the liver in the $F_{1}$ hybrids, the higher weight of the left kidney compared with the right one in hybrids of both sexes, and the greater relative weights of the heart and liver in females than in males. The morphological characters typical of the hybrids, such as the icicle-shaped heart, are also observed. As the share of cattle blood increases in backcross hybrids, their internal organs show more similarity to those of the cattle.

[Mammals Res. Inst., Polish Acad. Sci., 17-230 Białowieża, and Inst. Anim. Physiol., Agric. Acad., 03-849 Warszawa, Grochowska 272]
\end{abstract}

\section{INTRODUCTION}

The occurrence of hetorosis during the postnatal development of $F_{1}$ hybrids between the European bison and domestic cattle prompted us to carry out a close investigation of some internal organs. The commonest signs of heterosis in these hylbrids is the acceleration of growth and differentiation of tissues, the attainment of a large body weight and changes in metabolism ( $\mathrm{Kirpichnikov,} \mathrm{1960;} \mathrm{Hutt,} \mathrm{1972;} \mathrm{Kołą-}$ ta j, Krzanowska \& Wolański, 1973). The intense development 
of the Bialowieża $F_{1}$ hybrids caused that they reached a larger body weight and size than the initial forms in the period of great juvenile growth and at their adult age ( $\mathrm{K} \mathrm{r}$ a s in s k a, 1969).

The purpose of the present work was to find whether heterosis observed in the $F_{1}$ generation of hybrids has an effect on the size of the internal organs. At the same time an attempt was made to grasp possible regularities in the inheritance of the morphological characters of internal organs in hybrids in generations with different shares of blood of the initial forms.

Such organs as the liver, heart and kidneys, were subjected to a biometric analysis in this work. The spleen of hybrids is the subject of a separate paper (Pytel, Krasińska \& Węgrzyn, 1976). Data concerning both parental forms, the European bison and cattle, were used for comparison.

\section{MATERIAL AND METHODS}

The material for study consisted of the organs of 32 hybrids of different generations obtained at a slaughter analysis carried out in 1969-1973 (Table 1). The $F_{1}$ generation was represented only by material derived from adult animals, whereas the $B_{1}$ hybrids were divided into three groups withlin either sex.

The method of slaughter of all hybrids was similar and is described in a paper by Szulc, Tropilo \& Krasińska (1971). The hybrids, irrespective of what generation they belonged to, were fed according to the same principles, allowing for the physiological state, age and body weight, which secured a uniform state of animals in respect of their physical condition.

After their removal from the body cavities, the organs designed for study were weighed and fixed in $4 \%$ formalin. After fixation, which took at least 6 months, the organs were weighed again and their measurements were taken. Since the absolute weights of all organs decreased during fixation, the linear measurements must also have undergone changes, but seeing that this decrease concerned a three-dimensional solid body, the differences in dimensions in relation to the unfixed organs are not great. The organs were weighed to an accuracy of $1 \mathrm{~g}$ and measurements were taken to an accuracy of $1 \mathrm{~mm}$ by means of a pair of compasses, slide caliper and tape measure.

The weights of unfixed organs are given in absolute values and in relation to the body weight of hybrids. The significance of differences in weight between two kidneys was calculating according to Student's $t$ test for comparison of two independent groups.

Measurement of the liver was carried out by the method adopted for cattle (Eichel, 1925), where the right lobe includes the quadrat lobe, which is important to the determination of the length of lobes. Measurements of the heart were taken by Schubert's (1909) method, applied also for the European bison by Węgrzyn (1968). The kidneys were measured according to the data given by We h n (1924) and used for the European bison by Pilarski (1967).

No complete data concerning the morphological characters of the internal organs of the European bison and cattle were available for comparison. They chiefly concerned adult animals and in the case of the European bison were limited to one sex or based on scanty material. Papers by Schneider (1904), S ch u ber t (1909) 
and Eichel (1925) provide the most numerous and complete data about the morphological characters of the cattle organs. As regards the European bison, we based ourself on the investigations carried out by Pilarski (1967), Wegrzy n (1968) and P y tel \& Węg r z y n (1976).

\section{RESULTS}

\section{Liver}

1.1. Absolute and Relative Weight of Unfixed Liver

The liver of $F_{1}$ males outweighs that of females by $61.3 \%$, whereas in

Table 1

Material examined.

\begin{tabular}{|c|c|c|c|c|c|}
\hline No. & Name & Generation & Age, years & Body weight & Body length (oblique) \\
\hline & & & \multicolumn{2}{|c|}{ MALES } & \\
\hline 1. & Fakir & $F_{1}$ & 5 & 841 & 210 \\
\hline 2. & Farad & $\mathrm{F}_{1}$ & 6.5 & 1015 & 205 \\
\hline 3. & Filip & $F_{1}$ & 8 & 885 & 188 \\
\hline 4. & Facet & $F_{1}$ & 12.5 & 1080 & - \\
\hline 5. & Filon & $F_{1}$ & 13.5 & 805 & 194 \\
\hline 6. & Fest & $\mathrm{B}_{1}$ & 0.5 & 263 & 133 \\
\hline 7. & Felon & $\mathrm{B}_{1}$ & 0.5 & 286 & 135 \\
\hline 8. & Feld & $\mathrm{B}_{1}$ & 1.5 & 380 & 156 \\
\hline 9. & Fellach & $\mathrm{B}_{1}$ & 2.0 & 500 & 167 \\
\hline 10. & Festyn & $\mathrm{B}_{1}$ & 2.5 & 540 & 172 \\
\hline 11. & Fen & $\mathrm{B}_{1}$ & 3.5 & 580 & 157 \\
\hline 12. & Feb & $\mathrm{B}_{1}$ & 3.5 & 540 & 167 \\
\hline 13. & Feg & $\mathrm{B}_{1}$ & 3.5 & 552 & 172 \\
\hline 14. & Fey & $\mathrm{B}_{1}$ & 4.0 & 675 & 182 \\
\hline 15. & Fez & $\mathrm{B}_{1}$ & 4.5 & 613 & 165 \\
\hline 16. & Fetysz & $\mathrm{B}_{1}$ & 4.5 & 567 & 168 \\
\hline \multirow[t]{2}{*}{17.} & Fenix & $\mathrm{B}_{1}$ & 5.5 & 520 & 154 \\
\hline & \multicolumn{4}{|c|}{ FEMALES } & \\
\hline 1. & Fatima & $\mathrm{F}_{1}$ & 4.5 & 520 & 168 \\
\hline 2. & Filutka & $\mathrm{F}_{1}$ & 7.0 & 490 & 153 \\
\hline 3. & Fama & $F_{1}$ & 9.0 & 532 & 161 \\
\hline 4. & Feeria & $\mathrm{B}_{1}$ & 0.5 & 236 & 132 \\
\hline 5. & Felly & $\mathrm{B}_{1}$ & 1.0 & 279 & 136 \\
\hline 6. & Ferma & $\mathrm{B}_{1}$ & 1.5 & 284 & 138 \\
\hline 7. & Fema & $\mathrm{B}_{1}$ & 2.5 & 330 & 145 \\
\hline & Felpa & $\mathrm{B}_{1}$ & 4.5 & 552 & 163 \\
\hline 9. & Feska & $\mathrm{B}_{1}$ & 4.5 & 596 & 180 \\
\hline 10. & Fewa & $\mathrm{B}_{1}$ & 5.5 & 547 & 172 \\
\hline 11. & Fera & $\mathrm{B}_{1}$ & 6.5 & 504 & 168 \\
\hline 12. & Femina & $B_{1}$ & 7.5 & 449 & 160 \\
\hline 13. & Fela & $\mathrm{B}_{2}$ & 2.5 & 429 & 162 \\
\hline 14. & Ferajna & & 4.5 & 565 & 183 \\
\hline 15. & Fega & $\mathrm{B}_{2}$ & 4.5 & 498 & 178 \\
\hline
\end{tabular}

$F_{1}$ - hybrids first generation; $B_{1}$ - backcross hybrids; $1 / 4$ bison $3 / 4$ cattle $\mathrm{B}_{2}-$ backcross hybrids $1 / 8$ bison $7 / 8$ cattle

the $\mathrm{B}_{1}$ generation on the contrary the absolute weight of the liver of females is slightly higher $(2.5 \%)$ than that in males. In both generations of adult hybrids the relative weight of the liver in females is greater than 
in males (Fig. 1). It should be emphasized that the males of both generations have a greater body weight by as much as $80 \%$ in the $F_{1}$ generation and by $9 \%$ in the $B_{1}$ generation. The size of liver in males of both generations was proportional to their body weight (Fig. 1). In the group of adult females of both generations there is a great similarity in the
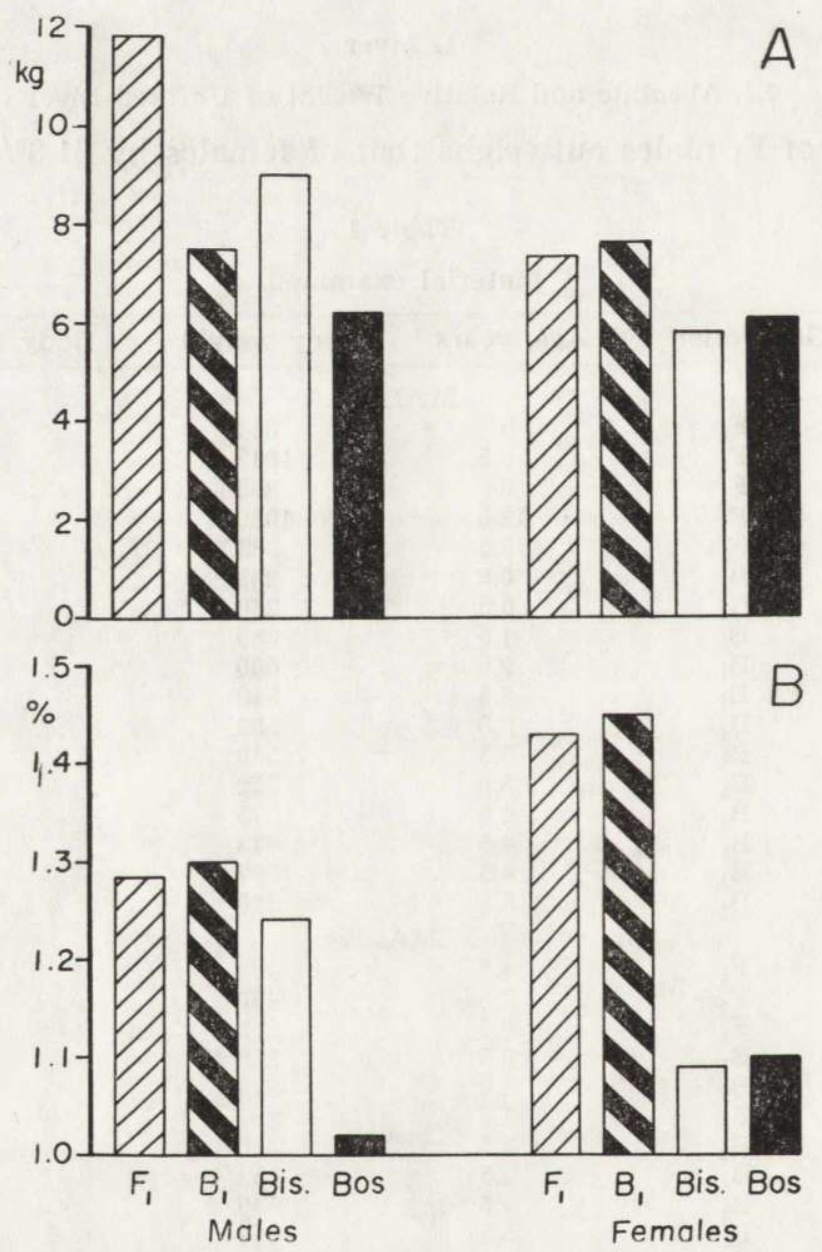

Fig. 1. Absolute (A) and relative (B) liver weight.

Bis. - Bison bonasus (after Pytel \& Węgrzyn, 1976), Bos-Bos taurus (after Eichel, 1925).

absolute and relative weight of the liver (Table 2), which is plain, if one takes into consideration the similarity of the body weight of these animals.

In the $B_{1}$ generation of hybrids of both sexes the highest values of the relative weight of liver is noted in young animals 1.5-2.5 years old and 


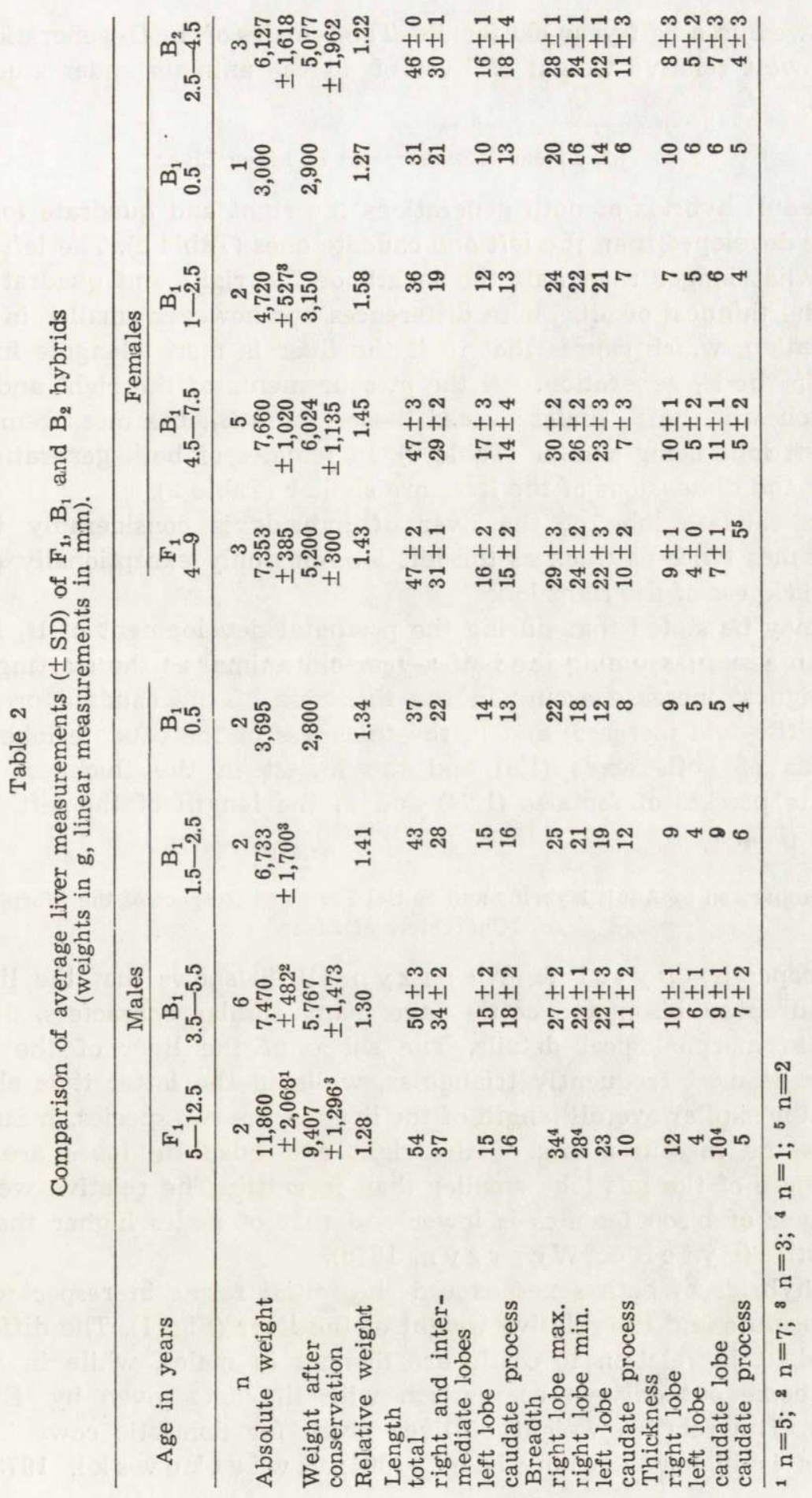


the lowest in a half-year old female. The females of the $\mathrm{B}_{2}$ generation have the lowest relative weight of liver of all the animals under study (Table 2).

\subsection{Linear Measurements of Fixed Liver}

In adult hybrids of both generations the right and quadrate lobes are better developed than the left and caudate ones (Table 2). The left lobe is somewhat longer than half the length of the right and quadrate lobes and the thinnest of all. These differences are however smaller in the $B_{1}$ generation, which causes that in it the liver is more elongate in shape than in the $F_{1}$ generation. All the measurements of the right and quadrate lobes in the $F_{1}$ males exceed those in the $B_{1}$, the measurements of the left lobe being similar (Table 2). In females of both generations the shape and dimensions of the liver are similar (Table 2).

The caudate lobe of the liver of hybrids is considerably thicker, sometimes twice as thick as the left lobe but only exceptionally exceeds the thickness of the right lobe.

It may be stated that during the postnatal development of $B_{1}$ hybrids of both sexes (assuming the half-a-year-old animal as the starting point) the highest increase occurs in the thickness of the caudate process in males (1.9-fold increase) and in the thickness of the caudate lobe in the hybrids of both sexes (1.8) and the lowest in the thickness of the caudate process of females (1.04) and in the length of the left lobe in males (1.1).

1.3. Comparison of Adult Hybrids and Initial Forms in Respect of the Morphological Characters of Liver

A paper by Pytel \& Weegrzyn (1976) shows that the livers of the European bison and cattle have many similar characters, differing only in morphological details. The shape of the liver of the former species is most frequently triangular, while in the latter it is elongate. With the similar overall length of the liver in the two species, in European bisons the measurements of the right and quadrate lobes are larger and those of the left lobe smaller than in cattle. The relative weight of the liver of bison females is lower and that of males higher than it is in cattle (Pytel \& Węgrzyn, 1976).

$\mathrm{F}_{1}$ hybrids of both sexes exceed the initial forms in respect of both the absolute and the relative weight of the liver (Fig. 1). The differences in weight in relation to cattle are distinct in males, while in females they come out only in comparison with the data given by Eichel (1925). The relative weight of liver given for domestic cows in other papers is higher (Schneider, 1904; Kwiatkowski, 1973). The 
absolute weight of liver in $B_{1}$ males is intermediate between those of $F_{1}$ and cattle, whereas in $\mathrm{B}_{1}$ females it is the highest (Fig. 1). In the hybrid females of both generations the relative weight of liver is higher than in males, just as it is in cattle ( $\mathrm{Schneider}, 1904$; E ichel, 1925) and inversely to the situation in the European bison (Pytel \& Węgc zy n, 1976) (Fig. 1).

In the liver of $F_{1}$ males the right and quadrate lobes show a stronger development as compared with the measurements of the left lobe, which is also the case with the liver of the European bison (Table 3). The livers of the females of both generations have the overall length

Table 3

Comparison of average liver measurements of adult hybrids, European bison and cattle (in $\mathrm{mm}$ ).

\begin{tabular}{|c|c|c|c|c|c|c|c|c|}
\hline \multirow{3}{*}{ Measurements } & \multicolumn{4}{|c|}{ Males } & \multicolumn{4}{|c|}{ Females } \\
\hline & \multicolumn{2}{|c|}{ Hybrids } & \multirow{2}{*}{$\begin{array}{c}\text { European } \\
\text { bison } 1\end{array}$} & \multirow[t]{2}{*}{ Cattle $^{2}$} & \multicolumn{2}{|c|}{ Hybrids } & \multirow{2}{*}{$\begin{array}{c}\text { Euro- } \\
\text { pean } \\
\text { bison } 1\end{array}$} & \multirow[t]{2}{*}{ Cattle $^{2}$} \\
\hline & $\mathrm{F}_{1}$ & $\mathrm{~B}_{1}$ & & & $\mathrm{~F}_{1}$ & $\mathrm{~B}_{1}$ & & \\
\hline \multicolumn{9}{|l|}{ Length } \\
\hline $\begin{array}{l}\text { whole liver } \\
\text { right and inter- }\end{array}$ & 537 & 489 & 531 & 533 & 467 & 467 & 561 & 557 \\
\hline mediate lobes & 370 & 342 & 383 & 300 & 307 & 292 & 396 & 307 \\
\hline left lobe & 152 & 155 & 152 & 233 & 160 & 175 & 168 & 250 \\
\hline caudate process & 162 & 178 & 202 & 162 & 153 & 145 & 217 & 156 \\
\hline \multicolumn{9}{|l|}{ Breadth } \\
\hline right lobe $\max$. & 340 & 266 & 390 & 310 & 290 & 298 & 378 & 329 \\
\hline left lobe & 232 & 223 & 216 & 268 & 220 & 230 & 206 & 270 \\
\hline $\begin{array}{l}\text { caudate process } \\
\text { Thickness }\end{array}$ & 105 & 107 & 94 & 100 & 103 & 73 & 92 & 102 \\
\hline right lobe & 121 & 105 & 104 & 90 & 88 & 97 & 88 & 84 \\
\hline left lobe & 42 & 58 & 44 & 37 & 42 & 46 & 38 & 37 \\
\hline
\end{tabular}

After: ${ }^{1}$ P ytel \& W ęgrzyn (1976); ${ }^{2}$ E ichel (1925).

smaller than it is in both initial forms. The thickness of the hepatic lobes in the hybrids of both generations is greater than in cattle, verging upon or even higher than that of the European bison. The measurements of the caudate process in the hybrids of both generations are smaller than in the European bison and approximate those in cattle (Table 3).

\section{Heart}

\subsection{Absolute and Relative Weight of Unfixed Heart}

In $F_{1}$ males the heart is heavier than in females on the average by $69.4 \%$, the situation being reversed as regards the relative weight. In adult $B_{1}$ hybrids the heart of males is on the average $25 \%$ heavier than the heart in females, but in contradistinction to what is observed in the $\mathrm{F}_{1}$ its relative weight is also higher in males than in females (Fig. 2). The size of heart in the hybrid males of both generations is proportional to 
the body weight (Table 4), whereas the $F_{1}$ females have a heavier heart, in relation to their body weight, than the $B_{1}$ females (Fig. 2).

During the postnatal development the relative weight of heart decreases with age in $\mathrm{B}_{1}$ hybrids of both sexes (one female, half a year old, was an exception). In $B_{2}$ females the relative weight of heart was the lowest compared with that of the other hybrids (Table 4).

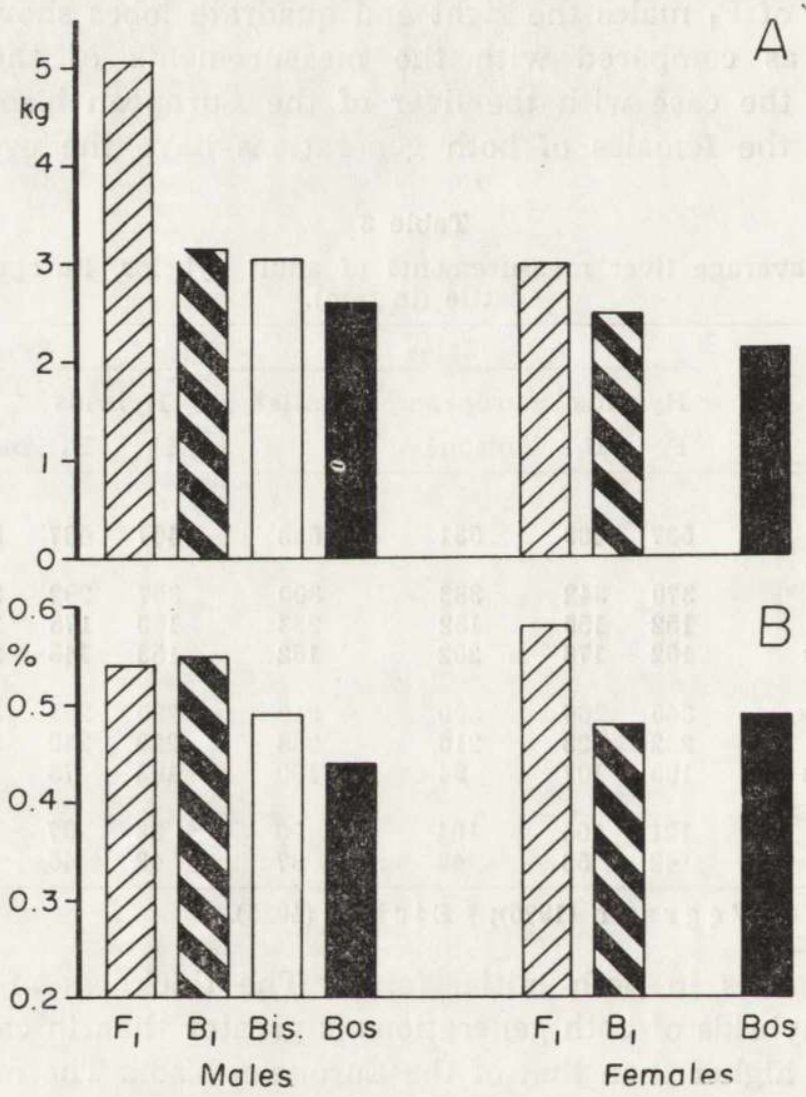

Fig. 2. Absolute (A) and relative (B) heart weight.

Bis.-Bison bonasus (after Węgrzy n, 1968), Bos-Bos taurus (after $\mathrm{S}$ c hne ide r, 1904).

\subsection{Measurements of Fixed Hearts}

In $F_{1}$ hybrids the heart has greater measurements in males than in females and in $B_{1}$ hybrids of both sexes all the measurements of the heart are similar (Table 4). During the postnatal development the heart of $B_{1}$ hybrids of both sexes shows a similar rate of increase. The height of the right ventricle increased most with age in comparison with the half-a-year-old animals (1.4-fold). 
The heart of $F_{1}$ males is higher and more flattened and in $B_{1}$ males more spherical. The heart of $F_{1}$ females is slendered than in the $B_{1}$.

2.3. Comparison of Adult Hybrids and Initial Forms in Respect of some Morphological Characters of Heart

W ęgrzyn's (1968) paper shows that there are some morphological differences between the hearts of the European bison and cattle. The heart of male European bisons has a higher absolute weight and relative weight and greater measurements than the heart of the bulls of cattle. It is higher and more flattened and in consequence it attains the shape of a cone, strongly dilated at the base and laterally flattened. The heart of female European bisons is lower but, like that of males, is also broader and more flattened than in domestic cows.

Table 4

Comparison of average heart measurements ( $\pm \mathrm{SD}$ ) of $\mathrm{F}_{1}, \mathrm{~B}_{1}, \mathrm{~B}_{2}$ hybrids (weights in $\mathrm{g}$, linear measurement - in $\mathrm{mm}$ ).

\begin{tabular}{|c|c|c|c|c|c|c|c|c|c|c|}
\hline \multirow[b]{2}{*}{$\begin{array}{l}\text { Group; } \\
\text { Age, years }\end{array}$} & \multirow[b]{2}{*}{$\mathrm{n}$} & \multicolumn{3}{|c|}{ Weight } & \multicolumn{3}{|c|}{ Height } & \multicolumn{2}{|c|}{ Width } & \multirow[b]{2}{*}{ 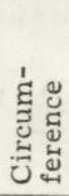 } \\
\hline & & 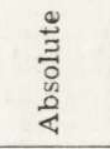 & 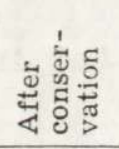 & 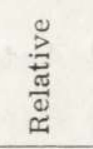 & 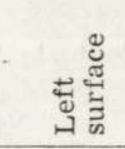 & 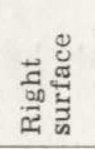 & 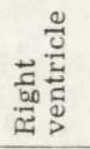 & 离 & 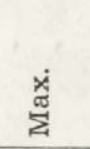 & \\
\hline $\begin{array}{l}\text { Males } F_{1} \\
5-12.5\end{array}$ & 3 & $\begin{array}{l}5,060 \\
\pm 1113\end{array}$ & $\begin{array}{l}4,133 \\
\pm 742\end{array}$ & 0.54 & $\begin{array}{l}233 \\
\pm 14\end{array}$ & $\begin{array}{l}202 \\
\pm 14\end{array}$ & $\begin{array}{l}162 \\
\pm 27\end{array}$ & $\begin{array}{l}158 \\
\pm 10\end{array}$ & $\begin{array}{l}207 \\
\pm 20\end{array}$ & $\begin{array}{l}586 \\
\pm 1\end{array}$ \\
\hline $\begin{array}{l}\text { Males } B_{1} \\
3.5-5.5\end{array}$ & 7 & $\begin{array}{l}3,157 \\
\pm 167\end{array}$ & $\begin{array}{l}2,630 \\
\pm 242\end{array}$ & 0.55 & $\begin{array}{l}205 \\
\pm 15\end{array}$ & $\begin{array}{l}179 \\
\pm 21\end{array}$ & $\begin{array}{l}152 \\
\pm 18\end{array}$ & $\begin{array}{l}136 \\
\pm 9\end{array}$ & $\begin{array}{l}190 \\
\pm 12\end{array}$ & $\begin{array}{l}481 \\
\pm 20\end{array}$ \\
\hline $\begin{array}{l}\text { Males } B_{1} \\
1.5-2.5\end{array}$ & 3 & $\begin{array}{l}2,727 \\
\pm 835\end{array}$ & $\begin{array}{l}2,148 \\
\pm 851\end{array}$ & 0.57 & $\begin{array}{l}181 \\
\pm 28\end{array}$ & $\begin{array}{l}169 \\
\pm 15\end{array}$ & $\begin{array}{l}150 \\
\pm 7\end{array}$ & $\begin{array}{l}128 \\
\pm 6\end{array}$ & $\begin{array}{l}171 \\
\pm 33\end{array}$ & $\begin{array}{l}451 \\
\pm 50\end{array}$ \\
\hline $\begin{array}{l}\text { Males } B_{1} \\
0.5\end{array}$ & 2 & 1,760 & 1,561 & 0.65 & 168 & 138 & 109 & 105 & 159 & 423 \\
\hline $\begin{array}{l}\text { Females } F_{1} \\
4-9\end{array}$ & 3 & $\begin{array}{l}2,987 \\
\pm 61\end{array}$ & $\begin{array}{l}2,700 \\
\pm 80\end{array}$ & 0.58 & $\begin{array}{l}214 \\
\pm 4\end{array}$ & $\begin{array}{l}203 \\
\pm 4\end{array}$ & $\begin{array}{l}170 \\
\pm 10\end{array}$ & $\begin{array}{l}134 \\
\pm 10\end{array}$ & $\begin{array}{l}187 \\
\pm 6\end{array}$ & $\begin{array}{l}477 \\
\pm 14\end{array}$ \\
\hline $\begin{array}{l}\text { Females } \mathrm{B}_{1} \\
4.5-7.5\end{array}$ & 5 & $\begin{array}{l}2,526 \\
\pm 353\end{array}$ & $\begin{array}{l}2,426 \\
\pm 267\end{array}$ & $0.48^{\circ}$ & $\begin{array}{l}205 \\
\pm 23\end{array}$ & $\begin{array}{l}172 \\
\pm 8\end{array}$ & $\begin{array}{l}147 \\
\pm 11\end{array}$ & $\begin{array}{l}134 \\
\pm 15\end{array}$ & $\begin{array}{l}189 \\
\pm 16\end{array}$ & $\begin{array}{l}523 \\
\pm 20\end{array}$ \\
\hline $\begin{array}{l}\text { Females } \mathrm{B}_{1} \\
1-2.5\end{array}$ & 2 & $\begin{array}{l}1,867 \\
\pm 354^{1}\end{array}$ & 1,586 & 0.62 & 163 & 154 & 127 & 103 & 159 & 432 \\
\hline $\begin{array}{l}\text { Females } B_{1} \\
0.5\end{array}$ & 1 & 1,200 & 1,250 & 0.51 & 165 & 135 & 105 & 105 & 151 & 422 \\
\hline $\begin{array}{l}\text { Females } \mathrm{B}_{2} \\
2.5-4.5\end{array}$ & 3 & $\begin{array}{l}2,163 \\
\pm 271\end{array}$ & $\begin{array}{l}2,138 \\
\pm 317\end{array}$ & 0.43 & $\begin{array}{l}196 \\
\pm 24\end{array}$ & $\begin{array}{l}162 \\
\pm 5\end{array}$ & $\begin{array}{l}129 \\
\pm 10\end{array}$ & $\begin{array}{l}128 \\
\mathrm{n}=2\end{array}$ & $\begin{array}{l}160 \\
n=2\end{array}$ & $\begin{array}{l}445 \\
\mathrm{n}=2\end{array}$ \\
\hline
\end{tabular}

The heart of $F_{1}$ males is characterized by its higher absolute and relative weight as compared with both initial forms (Fig. 2) and so is the heart of $F_{1}$ females in relation to domestic cows (lack of data does not permit a comparison with this organ in female European bisons). In $F_{1}$ hybrids, as in cattle, the relative weight of heart is higher in females than in males (Fig. 2). 
The absolute weight of heart in male $\mathrm{B}_{1}$ hybrids resembles that in the European bison and slightly exceeds this weight in cattle, while the relative weight is distinctly higher. In relative weight the heart of $B_{1}$ females approximate that of the domestic cow (Fig. 2).

The heart of $F_{1}$ males is more elongate than in both initial forms. All its measurements age greater than those characteristic of the heart of the bull of domestic cattle; the greatest differences occur in the circumference and height of the heart (Table 5). In width the heart of $\mathrm{B}_{1}$ bulls comes close to that of the males of domestic cattle, its height being greater. The heart of $F_{1}$ females is slenderer than in both initial forms (Table 5), while in $\mathrm{B}_{1}$ cows it has similar measurements to those of the heart of domestic cows, but is more spherical in shape.

Table 5

Comparison of heart measurements (averages \pm SD) of adult European bison and domestic cattle and their hybrids (in $\mathrm{mm}$ ).

\begin{tabular}{|c|c|c|c|c|c|c|c|c|c|}
\hline \multirow{3}{*}{ Measurements . } & \multicolumn{5}{|c|}{ Males } & \multicolumn{4}{|c|}{ Formales } \\
\hline & \multicolumn{2}{|c|}{ Hybrids } & \multirow{2}{*}{\multicolumn{2}{|c|}{$\begin{array}{l}\text { European bison }{ }^{1} \\
<6 \text { yrs. }>6 \text { yrs. }\end{array}$}} & \multirow[t]{2}{*}{ Cattle $^{2}$} & \multicolumn{2}{|c|}{ Hybrids } & \multirow{2}{*}{$\begin{array}{l}\text { European } \\
\text { bison }^{1}\end{array}$} & \multirow[t]{2}{*}{ Cattle $^{2}$} \\
\hline & $\mathbf{F}_{1}$ & $\mathrm{~B}_{1}$ & & & & & $\mathrm{~B}_{1}$ & & \\
\hline $\begin{array}{l}\text { Height (the left } \\
\text { surface) }\end{array}$ & $\begin{array}{l}233 \\
\pm 14\end{array}$ & $\begin{array}{l}205 \\
\pm 15\end{array}$ & 207 & 196 & $150-180$ & $\begin{array}{l}214 \\
\pm 4\end{array}$ & $\begin{array}{l}205 \\
\pm 23\end{array}$ & 181 & $170-220$ \\
\hline Maximal width & $\begin{array}{l}207 \\
\pm 21\end{array}$ & $\begin{array}{l}190 \\
\pm 12\end{array}$ & 211 & 204 & $174-199$ & $\begin{array}{l}187 \\
\pm 6\end{array}$ & $\begin{array}{l}189 \\
\pm 16\end{array}$ & 200 & $180-195$ \\
\hline Minimal width & $\begin{array}{l}158 \\
\pm 10\end{array}$ & $\begin{array}{l}136 \\
\pm 9\end{array}$ & 141 & 155 & $130-140$ & $\begin{array}{l}134 \\
\pm 10\end{array}$ & $\begin{array}{l}134 \\
\pm 15\end{array}$ & 149 & $125-150$ \\
\hline $\begin{array}{l}\text { Circumference } \\
\text { (below the } \\
\text { coronary groove) }\end{array}$ & $\begin{array}{l}586 \\
\pm 1\end{array}$ & $\begin{array}{l}481 \\
\pm 20\end{array}$ & 610 & 587 & $480-529$ & $\begin{array}{l}477 \\
\pm 15\end{array}$ & $\begin{array}{l}523 \\
\pm 20\end{array}$ & 595 & $475-517$ \\
\hline
\end{tabular}

After: ${ }^{1}$ Węgrzyn (1968); 2 S chubert (1909)

\section{Kidneys}

\subsection{Absolute and Relative Weight of Kidneys in Hybrids}

The absolute weights of both kidneys are higher in $F_{1}$ males than in corresponding females. On the contrary, in the $\mathrm{B}_{1}$ generation the kidneys of adult females have a higher absolute weight than have those of males (Table 6). It is interesting that in $F_{1}$ hybrids of both sexes the left kidney is heavier than the right one, but the difference is not statistically significant. The relative weight of the kidneys of $F_{1}$ hybrids is higher than in the $\mathrm{B}_{1}$ generation (Fig. 3 ).

During the postnatal development the relative weight of the kidneys of $B_{1}$ hybrids of both sexes decreases with age (Table 6).

\subsection{Linear Measurements of Fixed Kidneys}

In the $F_{1}$ generation all the measurements of both kidneys are greater in males than in females (Table 6 ). In adult $B_{1}$ hybrids both kidneys 
are longer in females and broader and higher in projection in males. All the measurements of the kidneys of $B_{1}$ males are smaller than in the $F_{1}$, whereas in $B_{1}$ females the kidneys are slightly longer but lower in projection and narrower than in the $F_{1}$ (Table 6). It is difficult to observe any regularity in the changes of measurements of the left and right kidneys according to sex and age during the postnatal development (Table 6).
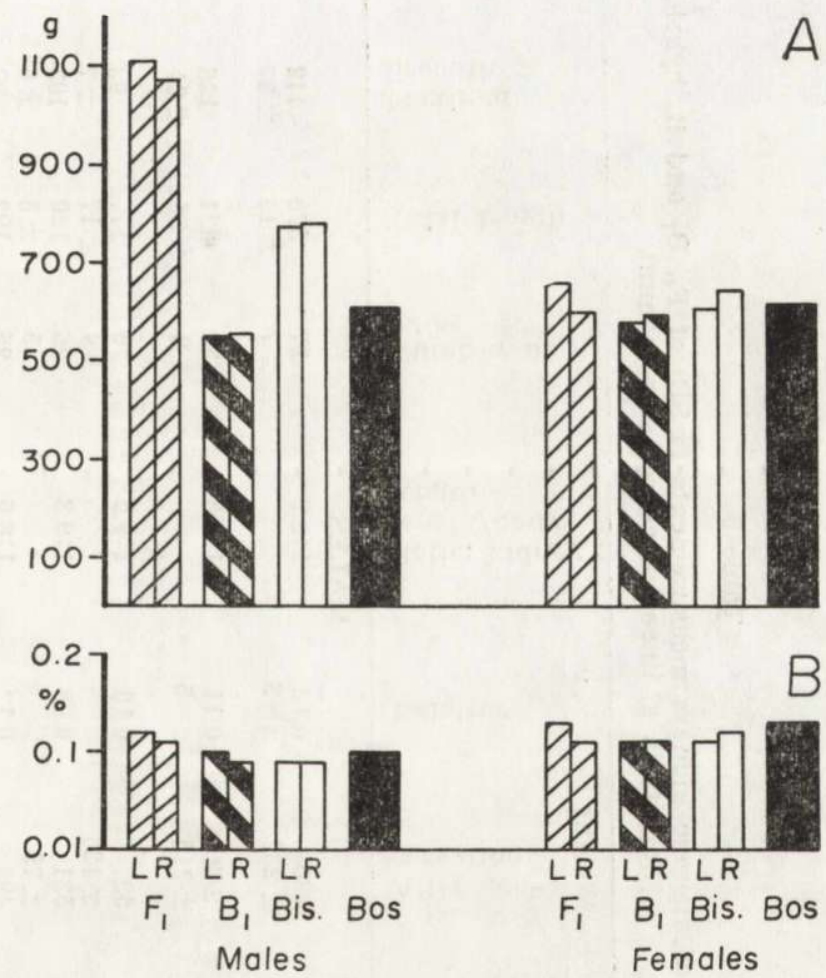

Fig. 3. Absolute (A) and relative (B) kidneys weight.

Bis. - Bison bonasus (after Pilarski, 1967), Bos-Bos taurus (atfer $\mathrm{Schum}$ mer \& Nickel, 1975). L- left, R-right.

\subsection{Relationship between Length of Kidneys and Oblique Length of Trunk}

In adult hybrids of both generations the kidneys of females are longer in relation to the length of trunk than age those of males. The shortest kidneys in relation to the trunk length occur in $\mathrm{B}_{2}$ females (Table 6). In the course of development this ratio grows in $\mathrm{B}_{1}$ females, whereas in adult males it falls slightly in comparison with the half-a-year-olds (Table 6). 


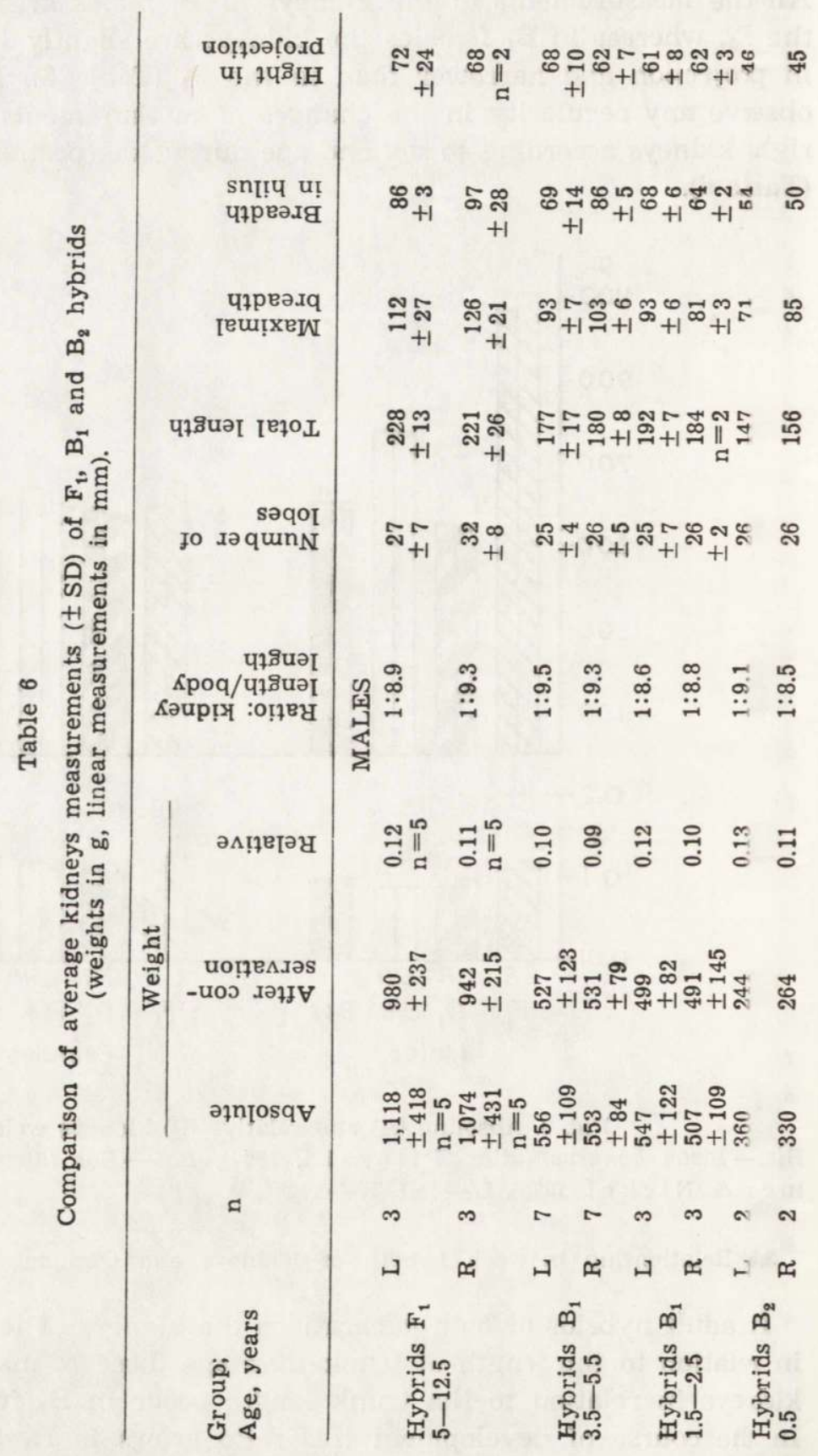




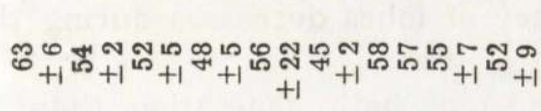

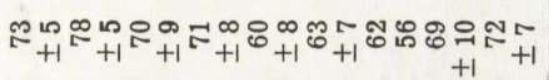

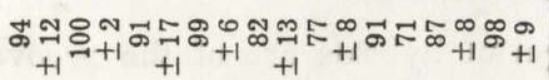

$$
\begin{aligned}
& \text { పีస్心 } \\
& \text { ล }
\end{aligned}
$$

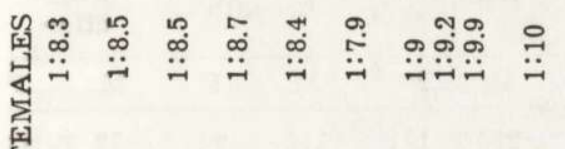

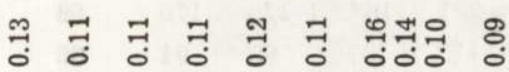

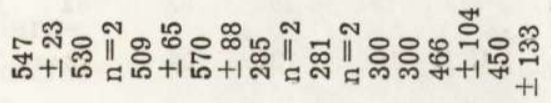

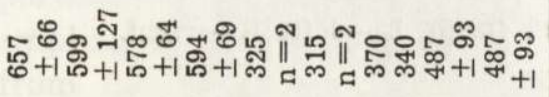

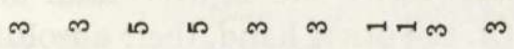

$$
\begin{aligned}
& \text { म भ म }
\end{aligned}
$$

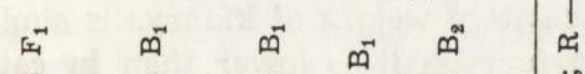

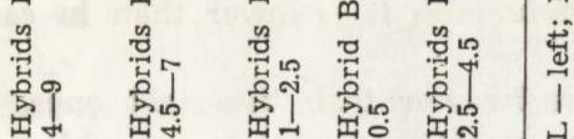




\subsection{Number of Kidney Lobes}

In all the groups of hybrids the number of kidney lobes varies in both kidneys. In the $B_{1}$ generation the number of lobes decreases during the postnatal development (Table 6).

There are more kidney lobes in males of both generation than in females. The kidneys of $F_{1}$ hybrids of both sexes have more lobes than those of $\mathrm{B}_{1}$ (Table 6).

3.5. Comparison of Kidneys of Adult Hybrids and Initial Forms in Respect of their Morphological Characters

As in both initial species, the kidneys of hybrids are of the grooved multipapillary type. The kidneys of males have higher absolute and relative weights than the kidneys of both initial forms. As regards $F_{1}$

\section{Table 7}

Comparison of kidneys measurements of adult European bison, domestic cattle and their hybrids (in $\mathrm{mm}$ ).

\begin{tabular}{|c|c|c|c|c|c|c|c|c|c|c|}
\hline \multirow[t]{2}{*}{ Group } & \multicolumn{2}{|c|}{$\begin{array}{c}\text { Number of } \\
\text { lobes }\end{array}$} & \multicolumn{2}{|c|}{$\begin{array}{l}\text { Ratio: len- } \\
\text { gth kidney } \\
\text { /body } \\
\text { length } \\
\end{array}$} & \multicolumn{2}{|c|}{ Length } & \multicolumn{2}{|c|}{$\begin{array}{l}\text { Maximal } \\
\text { breadth }\end{array}$} & \multicolumn{2}{|c|}{$\begin{array}{c}\text { Hight in } \\
\text { proje- } \\
\text { ction }\end{array}$} \\
\hline & M & $\mathrm{F}$ & M & $\mathrm{F}$ & M & $\mathrm{F}$ & M & $\mathrm{F}$ & M & $F$ \\
\hline \multirow{2}{*}{ Hybrids $\mathrm{F}_{1}$} & \multirow{2}{*}{$27-31$} & \multirow{2}{*}{$27-28$} & $1: 8.9$ & $1: 8.3$ & 228 & 191 & 112 & 94 & 72 & 63 \\
\hline & & & $1: 9.3$ & $1: 8.5$ & 221 & 188 & 126 & 100 & 68 & 54 \\
\hline \multirow{2}{*}{ Hybrids $B$} & \multirow{2}{*}{$24-25$} & \multirow{2}{*}{$23-24$} & $1: 9.5$ & $1: 8.5$ & 177 & 187 & 93 & 91 & 68 & 52 \\
\hline & & & $1: 9.3$ & $1: 8.7$ & 180 & 192 & 103 & 99 & 62 & 48 \\
\hline \multirow{2}{*}{$\begin{array}{ll}\text { European } & \text { L } \\
\text { bison }^{1} & R\end{array}$} & \multirow{2}{*}{\multicolumn{2}{|c|}{$27-28$}} & $1: 9.6$ & $1: 8.4$ & 192 & 191 & 105 & 82 & 92 & 62 \\
\hline & & & $1: 9.3$ & $1: 9.8$ & 192 & 164 & 121 & 104 & 73 & 70 \\
\hline $\begin{array}{l}\text { Hybrids } B_{2} \\
\text { Cattle }^{2}\end{array}$ & \multicolumn{2}{|c|}{$\begin{array}{l}23-26 \\
12-25\end{array}$} & & & & & & & & \\
\hline
\end{tabular}

After: 1 Pilarski (1967); ${ }^{2}$ Schummer \& Nickel (1975). L - left; R - right.

females, the left kidney is heavier and the right one lighter than the kidneys of females of the European bison. On the other hand, their absolute weight is higher and the relative weight slightly lower than in domestic cows (Fig. 3 ). In adult $B_{1}$ males the relative weight of kidneys is similar to that in both initial forms and in females it is lower than in cattle (Fig. 3).

In $F_{1}$ hybrids the left kidneys are heavier than the right ones, but the differences are not statisticaly significant, which resembles the situation observed in the kidneys of cattle (A u e rnheimer, 1909, 
1925; S isson, 1959) and is opposite to the state found in European bisons (Pilarski, 1967).

Since no data concerning the kidneys of cattle have been found in available literature, a comparison was carried out only with the European bison (Table 7). Both kidneys of $F_{1}$ males are longer and wider but thinner than those of European bisons and in $\mathrm{B}_{1}$ male they have considerably smaller dimensions than in this last species. However, the left kidney of males is always thicker than the right one (Table 7). The kidneys of $F_{1}$ and $B_{1}$ females show no major differences in measurements in comparison with the kidneys of females of the European bison, but the right kidney of hybrids is longer and as a result it has not the spherical shape characteristic of the right kidney of these last (Pila r$\mathrm{ski}$, 1967). Only the left kidney of $F_{1}$ males is longer in relation to the trunk length than it is in males of the European bison and $B_{1}$ hybrids; in the case of the right kidney this relation is similar in all males. In the female hybrids of both generations this relation is similar to female European bisons as regards the left kidney, whereas the right kidney of female bisons is conspicuously shorter in relation to the trunk length than it is in hybrids (Table 7).

The number of renal lobes in $F_{1}$ hybrids is slightly greater than in European bisons and considerably greater than in cattle (Table 7), whereas in $B_{1}$ and $B_{2}$ hybrids it lies within the limits of the mean values for cattle.

\section{DISCUSSION}

An analysis of the structural sexual dimorphism of mammals carried out by Glucksmann (1974) shows that in most species males are larger and have higher absolute weights of organs than females. The differences in the absolute weights of organs than females. The differences in the absolute weight of organs need not however be proportional to the body weight. At the same time Glucksmann (1974) emphasizes that the differences in the weight of organs may result from fat deposition, especially in females, and from the development of sustentacular tissue in the organs of males. In the considerations of the structural sexual dimorphism in hybrids of the European bison and cattle the body weight ratio between females and males was assumed, as in Glucksmann (1974), as the basis for comparison and the weight ratio of the internal organs under study was compared with it. If the value obtained exceeded the body weight ratio, the given organ was relatively larger in the male.

In $\mathrm{F}_{1}$ hybrids the body weight and the absolute weights of organs are higher in males than in females. However, in spite of the great 
difference in body weight $(80 \%)$ males have a relatively lighter liver, heart and kidneys than females (Table 8 ). In the $\mathrm{B}_{\mathbf{1}}$ generation they have a relatively greater weight of the heart and smaller weights of the liver and kidneys than females (Table 8).

Table 8

Ratios of body weight and organ weights for adult hybrids, European bison and domestic cattle, compared in different combinations.

\begin{tabular}{|c|c|c|c|c|c|c|}
\hline \multirow[b]{2}{*}{ Group } & \multirow[b]{2}{*}{$\mathrm{n}$} & \multicolumn{5}{|c|}{ Ratios } \\
\hline & & $\begin{array}{l}\text { Body } \\
\text { weight }\end{array}$ & Liver & Heart & $\underset{\text { left }}{\text { Kidney }}$ & $\begin{array}{c}\text { Kidney } \\
\text { right }\end{array}$ \\
\hline Males $F_{1}$ & 5 & 1.80 & 1.61 & 1.69 & 1.70 & 1.79 \\
\hline Females $F_{1}$ & 3 & & & & & \\
\hline Males $B_{1}$ & 7 & 1.09 & 0.97 & 1.25 & 0.96 & 0.93 \\
\hline Females $B_{1}$ & 5 & & & & & \\
\hline Males $\mathrm{F}_{1}$ & 5 & 1.60 & 1.58 & 1.60 & 2.0 & 1.94 \\
\hline Males $B_{1}$ & 7 & & & & & \\
\hline Females $F_{1}$ & 3 & 0.97 & 0.96 & 1.18 & 1.14 & 1.01 \\
\hline$\overline{\text { Females } \mathrm{B}_{1}}$ & 5 & & & & & \\
\hline Males $\mathrm{F}_{1}$ & 5 & 1.27 & 1.31 & 1.65 & 1.44 & 1.37 \\
\hline Males Bis. & 6 & & & & & \\
\hline Males $B_{1}$ & 7 & 0.79 & 0.82 & 1.03 & 0.71 & 0.70 \\
\hline Males Bis. & 6 & & & & & \\
\hline Males $\mathrm{F}_{1}$ & 5 & 1.72 & 1.91 & 1.95 & & 1.78 \\
\hline Nales Bos & $?$ & & & & & \\
\hline Males $\mathrm{B}_{1}$ & 7 & 0.99 & 1.20 & 1.21 & & 0.90 \\
\hline Males Bos & $?$ & & & & & \\
\hline Females $F_{1}$ & 3 & 0.97 & 1.27 & - & 1.08 & 0.93 \\
\hline Females Bis. & 3 & & & & & \\
\hline Females $B_{1}$ & 5 & 1.00 & 1.32 & - & 0.95 & 0.91 \\
\hline Females Bis. & 3 & & & & & \\
\hline Females $F_{1}$ & 3 & 1.13 & 1.21 & 1.35 & & 1.02 \\
\hline Females $\bar{B} o s$ & $?$ & & & & & \\
\hline Females $B_{1}$ & 5 & 1.16 & 1.26 & 1.14 & & 0.95 \\
\hline Females Bos & $?$ & & & & & \\
\hline
\end{tabular}

Bis. - European bison; Bos - cattle

The data conferning hybrids used to calculate the ratios were derived from the present study and those for the European bison and cattle from the following sources: European bison - weight of body an liver —Pytel \& Węgrzyn (1976), heart weight-Węgrzyn (1968), kidney weight - Pilarski (1967); Cattle: weight of body and heart $-\mathrm{Schneider}$ (1904), liver weight - E i chel (1925), kidney weight $\mathrm{Schummer} \& \mathrm{Nickel}(1975)$.

Admittedly, the phenomenon of heterosis occurs as a rule only in hybrids of the first generation and gradually subsides in the next generations ( $\mathrm{Kirpichnikov}, 1960 ; \mathrm{Hutt}$, 1972). One of the signs of heterosis is the attainment of greater body weights by hybrids as 
compared with the initial forms ( $\mathrm{Hutt}, 1972$; $\mathrm{K}$ olą $\mathrm{taj}$ et al., 1973). It is instructive to determine the body constituents responsible for this high weight. In her investigation of inter-racial hybrids of pigs Gleb in a (1966) demonstrated that they were characterized, among other details, by the intense growth of the liver and muscle fibres and the greater weight of the thyroid gland than in the initial forms. It has been found in our earlier studies that the $F_{1}$ hybrids between the European bison and cattle have a greater mass of muscular tissue and skin and a greater capacity of the stomach and intestines than have the initial forms (Pytel \& Krasińska, 1971; Pietrzykowski \& Krasińs ka, 1971; S z u 1 c et al., 1971).

An analysis of the degree of influence of heterosis upon the size of organs permits the statement that in $F_{1}$ hybrids of both sexes the heart and liver and in males the kidneys were heavier in relation to the body weight than in both initial forms. On the other hand, the right kidney of $F_{1}$ females was relatively lighter than in females of the European bison. The heart shows the greatest influence of heterosis (Table 8).

In the $\mathrm{B}_{1}$ generation the liver and heart were also found to have a greater weight in relation to their body weight as compared with the European bison and cattle, but the differences were smaller than in $F_{1}$ hybrids except for the relative weight of the liver of $B_{1}$ females (Table 8).

It may then be stated that heterosis had an effect on the size of internal organs in $F_{1}$ hybrids just as it had on the development of muscular tissue. Thus, in addition to the other constituents, the increased mass of internal organs contributed to the increase of the total body weight as compared with that in the initial forms.

Investigation of the degree of inheritability of morphological characters from the parental forms was difficult, because we had not at our disposal complete data for the initial forms, and the comparative material concerning particular organs examined was not derived from the same specimens. In addition, the differences in morphological characters between the European bison and cattle are not very distinct and often occur only in some anatomical details.

As regards proportions, the liver of $F_{1}$ hybrids was found to bear more similarity to the liver of the European bison and its left lobe to be backward as compared with the right and quadrate lobes, but the difference is smaller than in the European bison. As in this last species, the thickness of the right lobe of the liver is greater than in cattle, the difference being here still more conspicuous. The number of renal lobes in $\mathrm{F}_{1}$ hybrids approximates that in the European bison and so it is considerably higher than in cattle. The left kidneys of $F_{1}$ hybrids are heavier than the right ones, which is characteristic of cattle, inversely 
to the situation in the European bison. The relative weight of the liver and heart in the $F_{1}$ generation is higher in females than in males, as it is in cattle. Some specific morphological characters, different from those in the initial forms, are also observed in these hybrids, e.g. the shape of the heart, which is longer and slenderer than in the parental forms.

As the share of cattle blood increases in hybrids of the backross generations, the internal organs become more and more similar to those in cattle.

\section{REFERENCES}

1. A uernheimer O., 1909: Grössen- und Formvëränderungen der Baucheingeweide der Wiederkäuer nach der Geburt bis zum erwachsenen. Zustande: 44-49. Zürich.

2. A uernheimer O., 1925: Anatomie der Rindernieren. Berliner Trztl. Wschr. 44: 719-720. Berlin.

3. Eichel J., 1925: Masse, Formen und Gewichte der Lebern von Rinden und Schafen. Inaug. Diss.: 1-48.

4. Glebina E. I., 1955: O nekotoryh biologixeskih osobennostjah pomesnyh životnyh. Žurn. obšč. Biol., 16, 3: 80-85.

5. Glucksmann A., 1974: Sexual dimorphism in mammals. Biol. Rev., 49: $423-475$.

6. Hutt F. B., 1972: Genetyka zwierząt. Państw. Wyd. Roln. i Leśn.: 1-541. Warszawa.

7. Kirpichnikov V. S., 1960: Genetičeskie osnovy geterozisa. [In: „Voprosy evolucii, biogeografii, genetiki i selekcii «]: 94-98. Moskva, Leningrad.

8. Kolątaj A., Krzanowska H. \& Wolański N., 1973: Biologiczne podstawy heterozji. Państw. Wyd. Nauk.: 1-413. Warszawa.

9. $\mathrm{Kr}$ asinska M., 1969: The postnatal development of $\mathrm{F}_{1}$ hybrids of European bison and domestic cattle. Acta theriol., 14, 7: 69-117.

10. Kwiatkowski J., 1973: Próba oceny i porównania wartości rzeźnej krów rasy polskiej czerwonej, jersey i mieszańców $F_{1}$ tych ras. Prace i Materiały Zootechn., 3: 7-23.

11. Pietrzykowski W. \& Krasińska M., 1971: Characteristic of skin of European bison and domestic cattle hybrids. Acta theriol., 16, 33: 505-512.

12. Pilarski W., 1967: Układ moczowy żubra Bison bonasus (Lin n a e us, 1758). Msc.

13. Pytel S. \& Krasińska M., 1971: Morphology of the stomach and intestines in hybrids of European bison and domestic cattle. Acta theriol., 16, 31: $471-481$.

14. Pytel S. Krasińska M. \& Węgrzyn M., 1976: Morphology of the spleen in European bison and its hybrids with domestic cattle. Acta theriol., 22, 7: $141-149$.

15. Schneider J., 1904: Gewicht von Organen des Rindes. Z. f. Fleisch- und Milchhygiene, 14: 393-398.

16. Schubert F., 1909: Beitrage zur Anatomie des Herzen der Haussäugetiere. Diss., $1 \longrightarrow 90$. Dresden. 
17. Schummer A. \& Nickel R., 1975: Lehrbuch der Anatomie der Haustiere. P. Parey, 2: 1-430. Berlin, Hamburg.

18. Siss on S., 1959: The anatomy of the domestic animals. W. B. Saunder Company: 1-972. Philadelphia, London.

19. Szulc M., Tropilo J. \& Krasińska M., 1974: Dressing percentage and utility value of the meat of European bison and domestic cattle hybrids. Acta theriol., 16, 32: 483-504.

20. Wehn R., 1924: Anatomische und histologische Untersuchungen über der Bau der Nieren eines Flusspferdes. Diss. 1-15.

21. W ęgrzyn M., 1968: Blood vascular system of European bison. I. Morphology of the heart. Acta theriol., 13, 12: 177-218.

Accepted, June 10, 1976.

Małgorzata KRASIŃSKA i Waldemar PILARSKI

\section{ANALIZA MORFOLOGICZNA NIEKTORYCH NARZĄDOW WEWNETRZNYCH HYBRYDOW ŻUBRA Z BYDEEM DOMOWYM}

\section{Streszczenie}

Poddano analizie biometrycznej wątrobę, serce i nerki 32 hybrydów żubra $\mathrm{z}$ bydłem, różnych pokoleń (Tabela 1). Uzyskane wyniki porównano z danymi dla form wyjściowych. Mimo wysokiej różnicy w ciężarze ciała $(80 \%)$ samce $F_{1}$ mają proporcjonalnie do ciężaru ciała lżejsze wątrobę, serce i nerki niż samice (Tabela 8). W pokoleniu $\mathrm{B}_{1}$ samce mają proporcjonalnie większy ciężar serca a mniejszy wątroby i nerek niż samice.

Hybrydy $F_{1}$ obu płci przewyższają proporcjonalnie do ciężaru ciała obie formy wyjściowe ciężarem wątroby i serca oraz nerek u samców (Ryc. 1, 2, 3; Tab. 8). $\mathrm{W}$ pokoleniu $\mathrm{B}_{1}$ również wątroba i serce jest proporcjonalnie cięższe niż u żubra i bydła ale różnica jest mniejsza niż u hybrydów $\mathrm{F}_{1} \mathrm{z}$ wyjątkiem ciężaru względnego wątroby samic $B_{1}$. Można więc stwierdzić, że heterozja miała również wpływ podobnie jak na rozwój tkanki mięśniowej, na wielkość narządów wewnętrznych hybrydów pierwszego pokolenia, najwyraźniej w przypadku serca. W pokoleniu $\mathrm{B}_{1}$ wpływ heterozji na wielkość narządów maleie.

W ukształtowaniu narządów wewnętrznych hybrydów $\mathrm{F}_{1}$ dominację cech żubra obserwujemy w wykształceniu grubości wątroby, uwstecznieniu płata lewego w stosu.ıku do rozmiarów płata prawego i czworobocznego wątroby, ilości płatów nerek (Tabela 3, 7). Natomiast dominację cech bydla obserwujemy w rozmiarach wyrostka ogoniastego wątroby, większym ciężarze nerek lewych niż prawych u hybrydów $F_{1}$ obu płci (Tab. 3,6 ) oraz w większych ciężarach względnych wątroby i serca u samic $F_{1}$ niż u samców (Ryc. 1, 2). Obserwujemy też cechy morfologiczne odmienne od form wyjściowych, swoiste dla hybrydów jak na przykład soplowaty kształt serca hybrydów.

W miarę wzrostu udziału krwi bydła u mieszańców pokoleń wstecznych wzrasta podobieństwo ukształtowania narządów do bydła. 